\title{
EFFECTS OF AMITROLE, ZYTRON AND OTHER HERBICIDES OR PLANT GROWTH REGULATORS ON THE PEA APHID, ACYRTHOSIPHON PISUM (HARRIS), CAGED ON BROAD BEAN, VICIA FABA L.
}

\author{
A. G. Robinson ${ }^{T}$ \\ Department of Entomology, University of Manitoba, Winnipeg, Manitoba
}

[Received for publication December 22, 1960]

\begin{abstract}
Thirty herbicides or plant growth regulators were tested against the pea aphid, Acyrtbosipbon pisum (Harris), on broad bean, Vicia faba L. When amitrole at 300,200 and 100 p.p.m. of active ingredient in water was absorbed by the roots, fecundity of the adults was reduced and mortality of their progeny was 100,100 and 93.9 per cent respectively. No significant effects on fecundity occurred when amitrole was applied to the leaves or as a contact spray on adult aphids. When Zytron at 3,000, 2,000 and 1,000 p.p.m. of active ingredient in water was absorbed by the roots, mortality of adults was 100,100 and 95 per cent and of their progeny 100,100 and 98.6 per cent respectively. When Zytron was applied to the leaves at $8,000,4,000$ and 2,000 p.p.m. of active ingredient in water there was a mortality of adults of 85,70 and 50 per cent and of nymphs 75.1, 45.4 and 29.9 per cent. The lower mortality of nymphs occurred over a 5 -day period, indicating that the initial toxic effects from application to the leaves were soon lost. Mortality of nymphs refers to young aphids born alive and killed by the toxic effects of amitrole or Zytron. Twentyseven of the chemicals showed no effects on aphids caged on treated plants.
\end{abstract}

\section{INTRODUCTION}

A study was begun in 1958 at the University of Manitoba to determine possible effects, either deleterious or beneficial, of herbicides or plant growth regulators on the pea aphid, Acyrthosiphon pisum (Harris), caged on treated broad bean, Vicia faba L. Continuation of the project was encouraged by the discovery that maleic hydrazide applied by absorption through the roots caused a significant decrease in fecundity of wingless female pea aphids (apterous alienicolae). Preliminary results were reported by Robinson (4,5). Recently Adams (1) reported some mortality to the larvae of three species of coccinellid beetles predacious on aphids on barley when sprayed with 2,4-D and an increase in mean time to pupation in all groups except the 1-day-old larvae. Effects of gibberellic acid on growth and food consumption of Periplaneta americana $\mathrm{L}$. were reported by Siakotos and Dewey (6) and on rate of reproduction of Tetranychus telarius (L.) by Eichmeier and Guyer (2).

\section{MATERIALS AND METHODS}

During this study 30 herbicides or plant growth regulators were applied to broad bean plants by absorption through the roots and by dipping leaves. A wide range of chemicals was tested which included all those at present commonly used or under test in Western Canada. Twenty-seven of the chemicals are shown in Table 1. The other three were amitrole, Zytron and maleic hydrazide. All dosages used are reported as p.p.m. of active ingredient. The plants were grown in soil in the greenhouse until 2-4 inches high and then transplanted to vermiculite in $3 \frac{1}{2}$-inch clay pots. The

${ }^{1}$ Part of thesis submitted to the Faculty of Graduate Studies and Research, University of Manitoba, in partial fulfilment of requirements for the degree of Doctor of Philosophy. 
'TABLE 1. NAMES OF 27 HERBICIDES OR PLANT GROWTH REGLLATORS THAT HAD NO EFFECTS ON PEA APHIDS CAGED FOR 5 DAYS ON TREATED BROAD BEAN PLANTS

\begin{tabular}{|c|c|c|c|c|}
\hline \multirow{2}{*}{$\begin{array}{l}\text { Common }{ }^{1} \text { or } \\
\text { irade name }\end{array}$} & \multirow{2}{*}{ Chemical nane ${ }^{1}$} & \multirow{2}{*}{ Formulation ${ }^{2}$} & \multicolumn{2}{|c|}{$\begin{array}{l}\text { Highest rate p.p.m. } \\
\text { of active ingredient }\end{array}$} \\
\hline & & & $\begin{array}{c}\text { Root } \\
\text { ireatment }\end{array}$ & $\begin{array}{l}\text { Leaf } \\
\text { treatment }\end{array}$ \\
\hline atrazine & $\begin{array}{l}\text { 2-chloro-4-ethylanino-6- } \\
\text { isopropylamino-s-triazine }\end{array}$ & $50^{\circ}: \mathrm{HP}^{2}$ & 0.01 & 100 \\
\hline Avadex & $\begin{array}{l}\text { 2,3-dichloroallyl-diisopro- } \\
\text { pyithiol-carbamate }\end{array}$ & $50 \% \mathrm{EC}$ & 4,000 & 4.000 \\
\hline barbals & $\begin{array}{l}\text { 4-chloro-2-butynyl-N-(3- } \\
\text { chlorophenyl) carbamate }\end{array}$ & $12.5^{\circ}, \mathrm{EC}$ & 3,000 & 8,000 \\
\hline CDAA & $\begin{array}{l}\text { 2-chloro-N, N-dially- } \\
\text { acetamide }\end{array}$ & $\pm 7 c \mathrm{EC}$ & 100 & 1,000 \\
\hline CDEC & $\begin{array}{l}\text { 2-chloroally diethyldithio- } \\
\text { carbanate. }\end{array}$ & $46.4 \% \mathrm{EC}$ & 100 & 1,000 \\
\hline chlorazine & $\begin{array}{l}\text { 2-chloro-4,6-bis (diethyl- } \\
\text { amino)-s-triazine }\end{array}$ & $19.5 \%$ i EC & 1,000 & 1,000 \\
\hline $\mathrm{CIP}^{\mathrm{P}} \mathrm{C}$ & $\begin{array}{l}\text { isopropyl } \mathrm{N}-(3 \text {-chloropheny }) \\
\text { carbamate }\end{array}$ & $48 \% \mathrm{EC}$ & 3,000 & 10,000 \\
\hline $2,4-D$ & $\begin{array}{l}2,4 \text {-dichlorophenoxyacetic } \\
\text { acid }\end{array}$ & $50 \% \mathrm{EC}$ (amine) & 2 & 1,000 \\
\hline $\begin{array}{l}\text { dalapon } \\
4-(2,4-\mathrm{DB})\end{array}$ & $\begin{array}{l}\text { 2,2-dichloropropionic acid } \\
\text { 4-(2,4-dichlorophenoxy) } \\
\text { butyric acid }\end{array}$ & $74 \% \mathrm{~S}$ & $\begin{array}{r}1,000 \\
100\end{array}$ & $\begin{array}{r}10,000 \\
100\end{array}$ \\
\hline DMTT & $\begin{array}{l}\text { 3,5-dimethyltetrahydro- } 1,3-5, \\
2 \text { H-thiadiazine-2-1hione }\end{array}$ & $85 \% \mathrm{WP}$ & 100 & 1,000 \\
\hline DNBP & $\begin{array}{l}\text { 4,6-dinitro ortho secondary } \\
\text { butylphenol }\end{array}$ & $53 c$ EC (amine) & 300 & 1,000 \\
\hline eptam & $\begin{array}{l}\text { ethyl } N, N \text {-di-n-propylthiol- } \\
\text { carbannate }\end{array}$ & $78^{\circ}, \mathrm{EC}$ & 100 & 1,000 \\
\hline erbon & $\begin{array}{l}\text { 2-(2,4,5-trichlorophenoxy) } \\
\text { ethyl 2,2-dichloropropionate }\end{array}$ & $41.3 \% \mathrm{EC}$ & 1,000 & 10,000 \\
\hline $\begin{array}{l}\text { gibberellic acid } \\
\text { IPC }\end{array}$ & $\begin{array}{l}\text { potassium gibberellate } \\
\text { isopropyl N-phenylcarbamate }\end{array}$ & $\begin{array}{l}94 \% \mathrm{~S} \\
25 \% \mathrm{EC}\end{array}$ & $\begin{array}{l}1,000 \\
1,000\end{array}$ & $\begin{array}{l}1,000 \\
1,000\end{array}$ \\
\hline MCPA & $\begin{array}{l}2 \text {-methyl-4-chlorophenoxy- } \\
\text { acetic acid }\end{array}$ & $50 \% \mathrm{EC}$ (amine) & 8 & 10 \\
\hline $4-(\mathrm{M}, \mathrm{CPB})$ & $\begin{array}{l}\text { 4-(2-methyl-4-chloro- } \\
\text { phenoxy) butyric acid }\end{array}$ & $40 \% \mathrm{EC}$ (amine) & 100 & 1,000 \\
\hline monuron & $\begin{array}{l}\text { 3-(p-chlorophenyl)-1,1- } \\
\text { dimethylurea }\end{array}$ & $80 \% \mathrm{WP}$ & 1 & 1,000 \\
\hline $\begin{array}{l}\mathrm{NPA} \\
\text { sesone }\end{array}$ & $\begin{array}{l}\text { N-1-naphthylphthalamic acid } \\
\text { sodium } 24 \text {-dichloro- }\end{array}$ & Alanap-3 & 1,000 & 1,000 \\
\hline sesone & phenoxyethyl sulfate & $425 C$ FC (ester) & 1,000 & 8,000 \\
\hline silvex & $\begin{array}{l}\text { 2-(2,4,5-trichlorophenoxy }) \\
\text { propionic acid }\end{array}$ & $52.5 \%$ EL (ester) & 100 & 100 \\
\hline simazine & $\begin{array}{l}\text { 2-chloro-4,6-bis (ethylamino) } \\
\text {-s-triazine }\end{array}$ & $50 \% \mathrm{WH}$ & 1 & 100 \\
\hline $2,4,5-T$ & $\begin{array}{l}\text { 2,4,5-trichlorophenoxyacetic: } \\
\text { acid }\end{array}$ & $42.5 \% \mathrm{EC}$ (ester) & 0.1 & 0.1 \\
\hline $2,3,5,6-\mathrm{TBA}$ & $\begin{array}{l}\text { 2,3,5,6-tetrachlorobenzoic: } \\
\text { acid }\end{array}$ & $47.7 \% \mathrm{EC}$ & 100 & 1,000 \\
\hline $\begin{array}{l}2,3,6-\mathrm{TBA} \\
\mathrm{TCA}\end{array}$ & $\begin{array}{l}2,3,6 \text {-trichlorobenzoic acid } \\
\text { trichloroacetic acid }\end{array}$ & $\begin{array}{l}24.8 \% \mathrm{EC} \\
79 \% \mathrm{~S}\end{array}$ & $\begin{array}{r}100 \\
4,000\end{array}$ & $\begin{array}{r}1,000 \\
10,000\end{array}$ \\
\hline
\end{tabular}

${ }_{1}^{1}$ Common and chemical names from Weeds, Vol. 8, No. 3, July 1960, p. 490

${ }^{2} \mathrm{EC}=\mathrm{Enu}$ ]sifiale concentrate; $\mathrm{WP}=$ Wettalle powder; $S=$ Soluble powder 
treatment by absorption through the roots consisted of standing the pots in a dilute solution for 48 hours. The treatment of the leaves was applied by dipping one of the lower leaves in a dilute solution of the chemical for about 5 seconds to simulate field spraying. In all cases the highest concentrations used gave some visible plant injury such as epinasty, chlorosis or leaf blotching, but not plant death.

Forty-eight hours after application young adult wingless female pea aphids of approximately the same age were caged singly in replicates of 20 on treated plants. They remained on the plants for 5 days in a Coldstream Plant Growth Cabinet at a temperature set to hold at $69^{\circ} \mathrm{F}$., average relative humidity of about 70 per cent, with continuous lighting, and a nutrient solution of Plant Prod 20-20-20*. At the end of 5 days counts were made on mortality and fecundity.

Amitrole was applied by absorption through the roots in two separate tests, at rates of 300, 200 and 100 p.p.m., and at 100, 10 and 1 p.p.m., and by dipping leaves in solutions of 300,200 and 100 p.p.m. Amitrole was also applied as a contact spray on adult aphids at a treatment of 100 p.p.m. Zytron was applied by absorption through the roots at rates of 3,000,2,000 and 1,000 p.p.m. and by dipping leaves at rates of 8,000, 4,000 and 2,000 p.p.m.

The data on fecundity of aphids in the tests with amitrole were analysed statistically by a transformation using $\sqrt{x+0.5}$ suggested by Goulden (3).

\section{RESULTS AND DISCUSSION}

Of the 30 herbicides or plant growth regulators tested only amitrole, Zytron and maleic hydrazide [see Robinson $(4,5)$ ] had any effects on mortality or fecundity of the aphids. The remaining 27 which had no effects are listed in Table 1 with the highest rates of concentrations used.

Table 2 shows that amitrole at rates of 300, 200 and 100 p.p.m. by absorption through the roots caused a reduction in fecundity (total nymphs born) compared with the check, and a mortality of nymphs (total nymphs dead) of 100, 100 and 93.9 per cent respectively. Average number of live progeny of surviving adults differed significantly at the 1 per cent level from the check. Mortality of adults was low. At rates of 10 and 1 p.p.m. no effects on the aphids were noted. When amitrole was applied by dipping leaves in solutions of 300,200 and 100 p.p.m. there were no effects on the aphids. When this material was applied to aphids as a contact spray at 100 p.p.m., 13 adults died out of 20 , but there was no significant difference in fecundity of surviving aphids. These results indicate that amitrole is taken up through the roots of the broad bean plant and acts systemically to reduce fecundity of adults and to cause mortality of nymphs of the pea aphid.

When amitrole was applied to broad beans at 300 and 200 p.p.nu., either through the roots or the leaves, plants were severely damaged by the end of one week. At the above rates and at 100 p.p.m. terminal leaves were highly chlorotic. Dosages above 300 p.p.m. killed the plants.

* Plant Products Company, Port Credit, Ont. 
Table 2.-Mortality OF ADUlTS AND NYMPhs, AND PROGENY PER ADUlT, AFter 20 ADULT PEA APHIDS WERE CAGED FOR 5 DAYS ON BROAD BEAN PLANTS TREATED BY ABSORPTION THROUGH THE ROOTS OR BY LEAF TREATMENT WITH AMITROLE OR ZYTRON, OR SPRAYED WITH A CONTACT SPRAY OF AMITROLE

\begin{tabular}{|c|c|c|c|c|c|c|}
\hline \multirow{2}{*}{ Treatment } & \multirow{2}{*}{$\begin{array}{l}\text { Active } \\
\text { ingredient } \\
\text { p.p.m. }\end{array}$} & \multirow{2}{*}{$\begin{array}{l}\text { No. of } \\
\text { dead } \\
\text { adults }\end{array}$} & \multirow{2}{*}{$\begin{array}{l}\text { Total } \\
\text { nymphs } \\
\text { born }\end{array}$} & \multirow{2}{*}{$\begin{array}{l}\text { Total } \\
\text { nymphs } \\
\text { dead }\end{array}$} & \multicolumn{2}{|c|}{$\begin{array}{l}\text { Live progeny per } \\
\text { surviving adult }\end{array}$} \\
\hline & & & & & Average & $\begin{array}{l}\text { Transformed } \\
\text { average }^{1}\end{array}$ \\
\hline $\begin{array}{l}\text { Amitrole }{ }^{2} \\
\text { (root } \\
\text { absorption) }\end{array}$ & $\begin{array}{c}300 \\
200 \\
100 \\
\text { Check (Water) } \\
\end{array}$ & $\begin{array}{l}3 \\
1 \\
1 \\
0\end{array}$ & $\begin{array}{l}320 \\
473 \\
497 \\
662\end{array}$ & $\begin{array}{c}320 \\
473 \\
459 \\
0 \\
\end{array}$ & $\begin{array}{c}0 \\
0 \\
2.0 \\
33.1 \\
\end{array}$ & $\begin{array}{l}0.71^{* *} \\
0.71^{* *} \\
1.39^{* *} \\
5.74\end{array}$ \\
\hline $\begin{array}{l}\text { Amitrole } \\
\text { (root } \\
\text { absorption) }\end{array}$ & $\begin{array}{c}100 \\
10 \\
1 \\
\text { Check (Water) } \\
\end{array}$ & $\begin{array}{l}1 \\
0 \\
1 \\
1\end{array}$ & $\begin{array}{l}296 \\
603 \\
635 \\
652\end{array}$ & $\begin{array}{r}267 \\
0 \\
0 \\
0\end{array}$ & $\begin{array}{r}1.5 \\
30.1 \\
28.2 \\
34.3\end{array}$ & $\begin{array}{l}1.21^{* *} \\
5.52 \\
5.33 \\
5.87 \\
\end{array}$ \\
\hline $\begin{array}{l}\text { Amitrole } \\
\text { (leaf } \\
\text { dipping) }\end{array}$ & $\begin{array}{c}300 \\
200 \\
100 \\
\text { Check (Water) } \\
\end{array}$ & $\begin{array}{l}0 \\
0 \\
0 \\
1 \\
\end{array}$ & $\begin{array}{l}636 \\
635 \\
617 \\
565\end{array}$ & $\begin{array}{l}0 \\
0 \\
0 \\
0\end{array}$ & $\begin{array}{l}31.8 \\
31.7 \\
30.8 \\
29.7\end{array}$ & $\begin{array}{l}5.65 \\
5.57 \\
5.56 \\
5.47 \\
\end{array}$ \\
\hline $\begin{array}{l}\text { Amitrole } \\
\text { (contact } \\
\text { spray) }\end{array}$ & $\begin{array}{c}100 \\
\text { Check (Water) }\end{array}$ & $\begin{array}{r}13 \\
4\end{array}$ & $\begin{array}{l}220 \\
445\end{array}$ & $\begin{array}{l}0 \\
0\end{array}$ & $\begin{array}{l}25.7 \\
27.6\end{array}$ & $\begin{array}{l}5.08 \\
5.14\end{array}$ \\
\hline $\begin{array}{l}\text { Zytron } \\
\text { (root } \\
\text { absorption) }\end{array}$ & $\begin{array}{c}3,000 \\
2,000 \\
1,000 \\
\text { Check (Water) }\end{array}$ & $\begin{array}{r}20 \\
20 \\
19 \\
0\end{array}$ & $\begin{array}{r}15 \\
29 \\
70 \\
503\end{array}$ & $\begin{array}{l}15 \\
29 \\
69 \\
32\end{array}$ & $\frac{-}{E}$ & 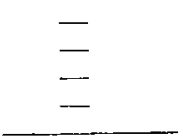 \\
\hline $\begin{array}{l}\text { Zytron } \\
\text { (leaf } \\
\text { dipping) }\end{array}$ & $\begin{array}{c}8,000 \\
4,000 \\
2,000 \\
\text { Check (Water) }\end{array}$ & $\begin{array}{r}17 \\
14 \\
10 \\
3\end{array}$ & $\begin{array}{l}205 \\
271 \\
331 \\
402\end{array}$ & $\begin{array}{r}154 \\
123 \\
111 \\
18\end{array}$ & $\begin{array}{l}\overline{21.5} \\
21.7 \\
21.2\end{array}$ & E \\
\hline
\end{tabular}

1 Transformed by the formula $\sqrt{\mathrm{x}+0.5}$

3-amino-1, 2,4-triazole (25\% emulsifiable concentrate)

${ }^{3} 0-2$.4-dichlorophenyl 0-methyl isopropylphosphoroamidothioate (25\% emulsifiable concentrate)

**Significant at the $1 \%$ level

When Zytron was applied by absorption through the roots at rates of $3,000,2,000$ and 1,000 p.p.m., mortality of adults was 100, 100 and 95 per cent and of nymphs 100, 100 and 98.6 per cent respectively (Table 2). When Zytron was applied to the leaves at 8,000, 4,000 and 2,000 p.p.m., mortality of adults was 85, 70 and 50 per cent and of nymphs 75.1, 45.4 and 29.9 per cent respectively. The lower mortality of nymphs occurred over a 5-day period, indicating that the initial toxic effects through dipping the leaves were soon lost. Surviving adults reproduced normally and the averages of their live progeny were nearly identical. There was only slight plant injury at the rates used. These results show that Zytron acts on aphids as an insecticide, probably systemic, although there may have been some fumigant action. The insecticidal action of Zytron on ants in lawns has been reported by Watson and Leasure (7). 


\section{ACKNOWLEDGEMENTS}

The assistance of G. Friesen, Department of Plant Science, University of Manitoba, in technical advice on herbicides, and for supplying most of the samples used, is gratefully acknowledged. Dow Chemical of Canada, Ltd., Sarnia, Ont., supplied the formulation of Zytron. Velsicol Corporation, Chicago, Ill., kindly donated 10 grams of 94 per cent pure gibberellin. Naugatuck Chemicals, Elmira, Ont., supplied samples of $\mathrm{MH}_{30}$ amine.

\section{REFERENCES}

1. Adams, J. B. Effects of spraying 2,4-D amine on coccinellid larvae. Can. J. Zoology 38:285-288. 1960.

2. Eichmeier, J., and G. Guyer. An evaluation of the rate of reproduction of the two-spotted spider mite reared on gibberellin-treated bean plants. J. Econ. Entomol. 53:661-664. 1960.

3. Goulden, C. H. The application of statistics in entomological research. Proc. Entomol. Soc. Manitoba 1:29-31. 1945.

4. Robinson, A. G. Note on fecundity of the pea aphid, Acyrthosipbon pisum (Harris), caged on broad bean, Vicia faba L., treated with various plant growth regulators. Can. Entomologist 91:527-528. 1959.

5. Robinson, A. G. Effect of maleic hydrazide and other plant growth regulators on the pea aphid Acyrtbosiphon pisum (Harris), caged on broad bean, Vicia faba L. Can. Entomologist 92:494-499. 1960.

6. Siakotos, A. N., and J. E. Dewey. The effects of a diet containing gibberellic acid on the growth and food consumption of Periplaneta americana L. J. Econ. Entomol. 52:1214-1215. 1959.

7. Watson, A. J., and J. K. Leasure. Zytron - a promising material for crabgrass control. In "Down to Earth" 15(3):2-5. Dow Chemical Company, Midland, Mich. 1959. 